\title{
The Digital Atlas of Ancient Life: delivering information on paleontology and biogeography via the web
}

\author{
Jonathan R. Hendricks, Alycia L. Stigall, and Bruce S. Lieberman
}

The fundamental data of paleontology consist of taxonomically identified specimens of known spatiotemporal provenance that are curated in museum collections. Analyses of these data can lead to insights into biostratigraphy, macroevolution, biogeography, phylogeny, and paleoecology. Although historical collections may contain specimens of vague or indeterminate geographic and stratigraphic position, most paleontologists have recorded these data with a high degree of precision for many years. One challenging problem with using paleontological collections for research, however, is making correct identifications of fossil material at lower taxonomic levels-in particular species, but also at the genus level. One aspect of the challenge is philosophical in nature, and involves the human activity of circumscribing species and higher taxa such that they best approximate biological reality (see Hendricks et al., 2014; Allmon, in press). This activity is the concern of the systematist, who makes such decisions based on expert knowledge of a given group. Another con- cern-which we focus on here-is practical in nature and has to do with identifying fossil specimens in hand sample and attaining information about the spatiotemporal occurrences of taxa from what may be far-flung museum collections.

Short of having in-depth knowledge of a particular group, identifications of fossils at lower taxonomic levels still largely rely upon access to printed literature, such as regional guides (e.g., Linsley, 1994; Petuch, 1994; Feldmann and Hackathorn, 1996; Davis, 1998; Peterson and Peterson, 2008; Wilson, 2014) and systematic treatments (e.g., Hendricks, 2009, 2015; Rode and Lieberman, 2002; Stigall et al., 2014a; Wright and Stigall 2013, 2014), or major compendia such as the Treatise of Invertebrate Paleontology (see Selden, 2012). Such literature may be expensive, locked behind journal paywalls, out-of-print, and/or may also contain technical jargon that is inaccessible to nonprofessionals and students, especially those new to paleontology. An additional problem presented by older literature is that it may not reflect current

Keywords: paleontology; digitization; fossils; museums; biogeography; evolution

Jonathan R. Hendricks. Department of Geology, San José State University, 307 Duncan Hall, One Washington Square, San José, California 95192, USA

and Paleontological Research Institution. 1259 Trumansburg Road, Ithaca, New York 14850, USA jonathan.hendricks@sjsu.edu

Alycia L. Stigall. Department of Geological Sciences and Ohio Center for Ecology and Evolutionary Studies, Ohio University, 316 Clippinger Laboratories, Athens, Ohio 45701, USA stigall@ohio.edu

Bruce S. Lieberman. Biodiversity Institute and Department of Ecology \& Evolutionary Biology, University of Kansas, 1345 Jayhawk Blvd., Dyche Hall, Lawrence, Kansas 66045, USA blieber@ku.edu 
taxonomic nomenclature. Finally, printed literature itself is starting to have less appeal to many younger professional and amateur paleontologists, many of whom often go to the Internet first for information.

An early and important development in the transition from print to digital presentations of fossils was the PaleoBase series (e.g., MacLeod, 2001, 2003, 2010; MacLeod and Henderson, 2007). This series, which provides digital guides to both macro- and microfossils, emphasizing the high-quality specimens in the collections of The Natural History Museum, London, is available as a relational database via compact disk, though it is not available as a free, online resource. Other seminal developments include the numerous useful web resources for paleontology that have been developed. The early standards in this regard were set first by the University of California Museum of Paleontology (www.ucmp.berkeley.edu/exhibits/ index.php) and the Paleontology Portal (www.paleoportal.org). Subsequently, the Paleobiology Database (www.paleobiodb.org) has also become a frequently used resource. Unprocessed, raw paleontological occurrence data may now be directly downloaded from many online museum databases and corresponding portals (e.g., the Integrated Digitized Biocollections database, iDigBio: www.idigbio.org), but these datasets-especially if large-are often incomprehensible on their own and provide little help with either identifying or enhancing understanding of fossil discoveries. Most of these high-quality, successful, and admirable resources are not specifically structured to assist with the identification of fossil species, though there are some notable exceptions, including the website of the Cincinnati Dry Dredgers (drydredgers.org). Thus, new open-access resources are needed for both avocational and professional paleontologists.

To this end, we have developed the freely accessible Digital Atlas of Ancient Life: www.digitalatlasofancientlife.org/. Although the noun "atlas" is typically used to refer to a bound collection of maps, another use of the term is a "volume containing illustrative plates, large engravings, etc., or the conspectus of any subject arranged in tabular form" (Oxford English Dictionary, 2014). We apply the term in both senses, as we seek to provide photographic aids and associated content to help identify fossils, as well as to generate maps that demonstrate how species' ranges vary over geological time scales. Here, we present the digital atlas project as a model for how web-based resources might be employed-especially in synthesis with existing museum databasing and digitization initiatives-to assist avocational, student, and professional paleontologists with fossil identifications by providing expert knowledge when it is not otherwise directly available. In short, we view the digital atlas project as an attempt to provide expertly curated, focused context for the abundance of newly digitized paleontological data that are now becoming available online. We also comment below on the potential of the Digital Atlas of Ancient Life to serve as a new resource for K-16 education and outreach.

\section{PROJECT OVERVIEW}

\section{Focus}

Generating a comprehensive atlas of ancient life-especially at the species level-would be a daunting task, whether undertaken in print or online. Even generating a simple listing of a majority of the described fossil species would be a massive endeavor, and this is likely why no such list exists (the closest printed resource for marine animal fossils is Sepkoski's [2002] compendium, which was tabulated at the generic level). Just as a comprehensive, global list of plant species would not be particularly useful to an amateur botanist trying to learn his or her local flora, a comprehensive listing of fossil species (or even an atlas) would present an overwhelming amount of information and is perhaps more likely to result in misidentification than a correct name.

Generating multiple digital atlases, each focused on a particular region and time period, is a more manageable and useful approach. Avocational paleontologists and students in paleontology classes are often interested in building fossil collections from localities near where they live, which are often from a single geological period. Likewise, paleontological research is frequently focused on temporally restricted fossil occurrences, often at regional scales. Just as Roger Tory Peterson recognized that field guides should be composed at the regional scale, embodied in his classic and highly effective works on birds (e.g., Peterson, 1980), it is most useful for digital atlases of fossils to do the same. The development of three open access digital atlases are currently underway:

1. The Ordovician Atlas of Ancient Life: Cincinnati Region United States (www.ordovicianatlas.org/).

2. The Pennsylvanian Atlas of Ancient Life: Midcontinent United States (pennsylvanianat- 
las.org/).

3. The Neogene Atlas of Ancient Life: Southeastern United States (neogeneatlas.org/).

Our choice to develop initial digital atlases for these three systems was based on three criteria: 1) interest among avocational and/or professional collectors; 2) availability of major museum collections from which corresponding fossil images, as well as stratigraphic and geographic occurrence data, could be attained; and 3) research potential for paleoecological, paleobiogeographic, and macroevolutionary studies.

The Ordovician fossils of the Cincinnati region-including southwestern Ohio, southeastern Indiana, and northern Kentucky-have factored importantly in our global understanding of Late Ordovician geology and paleontology for over a century. Corresponding strata contain a rich assortment of marine invertebrate fossils (especially brachiopods, trilobites, bryozoans, and echinoderms) that have been the subjects of numerous paleobiological studies (reviewed in Meyer and Davis, 2009). Avocational paleontologists-including members of the aforementioned Cincinnati Dry Dredgers, a fossil club established in 1942-have also heavily collected these strata and have contributed to our scientific understanding of these rocks through new discoveries, educational outreach, and collaborations with professionals (e.g., Morris and Felton, 1993; Kallmeyer and Donovan, 1998). These strata record a series of sea level fluctuations, shifting oceanic conditions, and a regional biological invasion event, the Richmondian Invasion. Thus, studies of Cincinnatian fossils have provided key insights into community structure and species stability across intervals of environmental change and biotic immigration events (e.g., Holland and Patzkowsky, 2007; Stigall 2010, 2014). The Ordovician Atlas is being developed using the holdings of the Ohio University Invertebrate Paleontology Collection, the Limper Museum at Miami University, and the Cincinnati Museum Center. For additional details on the Ordovician Atlas of Ancient Life, see Stigall et al. (2014b).

Fossils of the Pennsylvanian strata of the midcontinent United States-which outcrop from Texas to lowa-are very well represented by the extensive collections of the Division of Invertebrate Paleontology at the University of Kansas (KU) Biodiversity Institute and Natural History Museum. Many of these collections were made through the research activities of $\mathrm{KU}$ paleontologists, including Raymond C. Moore, Roger Kaesler, A.J. Rowell, and their colleagues and students. As most of the studies conducted by these workers had a strong stratigraphic component, these collections-which form the basis of the Pennsylvanian Atlas of Ancient Life-are associated with a high degree of stratigraphic precision. Because of this, they are particularly useful for investigating the responses of species to ancient climatic changes, especially as recorded by the cyclothems that characterize a significant portion of the rock record in this region (e.g., Holterhoff, 1996; Algeo and Heckel, 2008).

Finally, fossils from the extraordinary shell beds that comprise much of the Neogene fossil record of the southeastern United States have been heavily collected and researched since the mid-19th century. Modern study of these fossils has been facilitated by the development of aggregate quarries and other excavation activities that have exposed numerous new localities in this topographically low-lying region, particularly in Florida. Although entry into most commercial shell quarrying operations has become difficult, this was not always the case and very large collections of specimens-particularly mollusks, but also including corals, echinoids, brachiopods, and crustaceanswere made in the mid-to-late $20^{\text {th }}$ century when collecting was more feasible. Research on these fossils has ranged from systematic studies and compilations (e.g., Olsson and Harbison, 1953; DuBar, 1958; Olsson and Petit, 1964; Lyons, 1991; Petuch, 1991, 1994; Campbell, 1993; Hendricks, 2009) to investigations of the responses of species-some of which are still extant-to regional paleoenvironmental changes during the Plio-Pleistocene (e.g., Stanley, 1986; Allmon et al., 1996; Saupe et al., 2014a). Major collections of Neogene fossils from the southeastern United States are present at several large U.S. museums. One of these museums is the Florida Museum of Natural History (FLMNH); the comprehensive collections of the FLMNH were used to develop the Neogene Atlas of Ancient Life.

\section{Key Components and Underlying Data}

Each digital atlas is structured to direct the user to pages focused on individual fossil species. Every species-level page features taxonomic information, stratigraphic and geographic occurrence data, and one or more photographs of the taxon (Figures 1-3). The taxonomic classifications on each species page follow up-to-date nomenclature based on expert consensus. Each higher-level taxonomic name (genus to phylum) on the species page is hyperlinked to a page with information about that taxon and photographs of specimens 


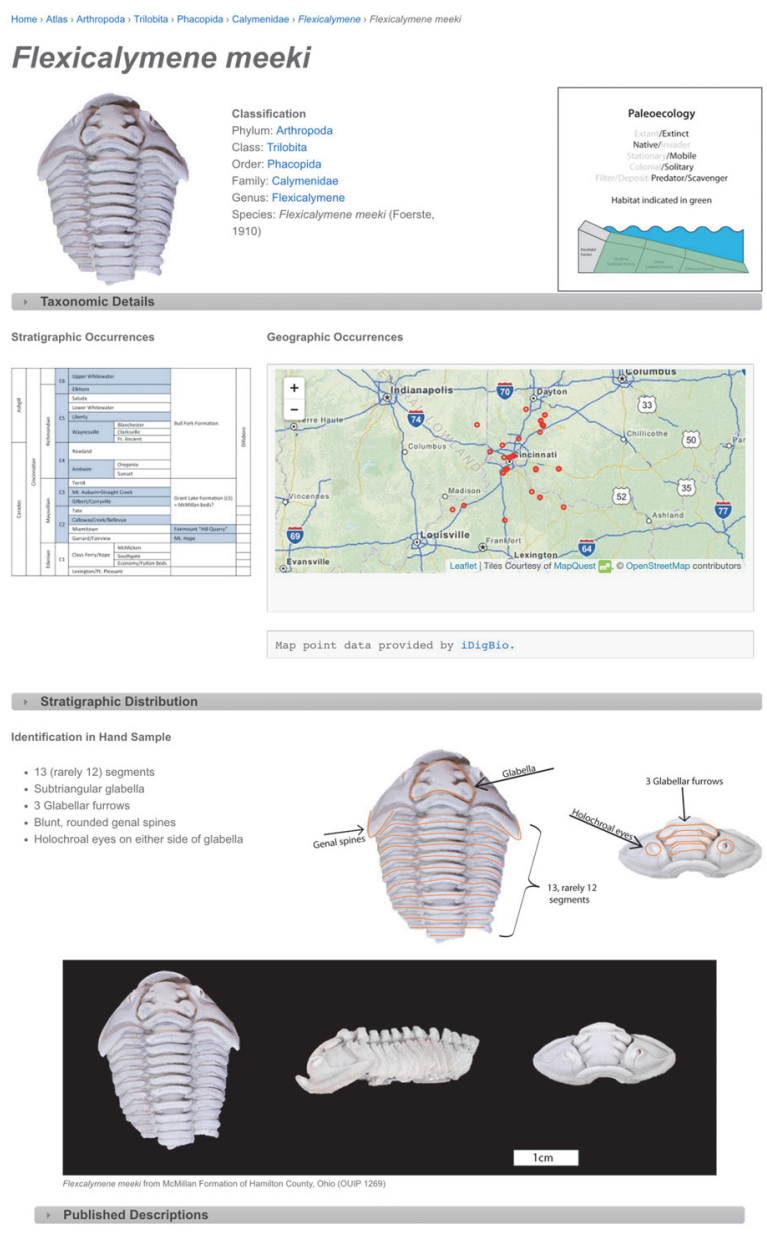

FIGURE 1. Composite screenshot of the Ordovician Atlas page for the trilobite species Flexicalymene meeki (www.ordovicianatlas.org/atlas/arthropoda/trilobita/phacopida/calymenidae/flexicalymene/flexicalymenemeeki). The bars labeled "Taxonomic Details", "Stratigraphic Distribution", and "Published Descriptions" dropdown to provide additional information on species synonymy, stratigraphic occurrences, and quoted excerpts of published descriptions, respectively.

belonging to immediately subordinate taxa. As an example, the Ordovician Atlas page on the Class Trilobita (www.ordovicianatlas.org/atlas/arthropoda/trilobita/) provides information about the geologic range, paleoecology, and characteristics of trilobites, and also provides linked images of the four orders of Cincinnatian trilobites (see Figure 4).

The geographic and stratigraphic occurrence data presented for each species are derived from georeferenced (c.f., Chapman and Wieczorek, 2006) locality data associated with the databased museum collections identified above. Geographic data associated with the Neogene Atlas are currently presented both qualitatively (e.g., southern

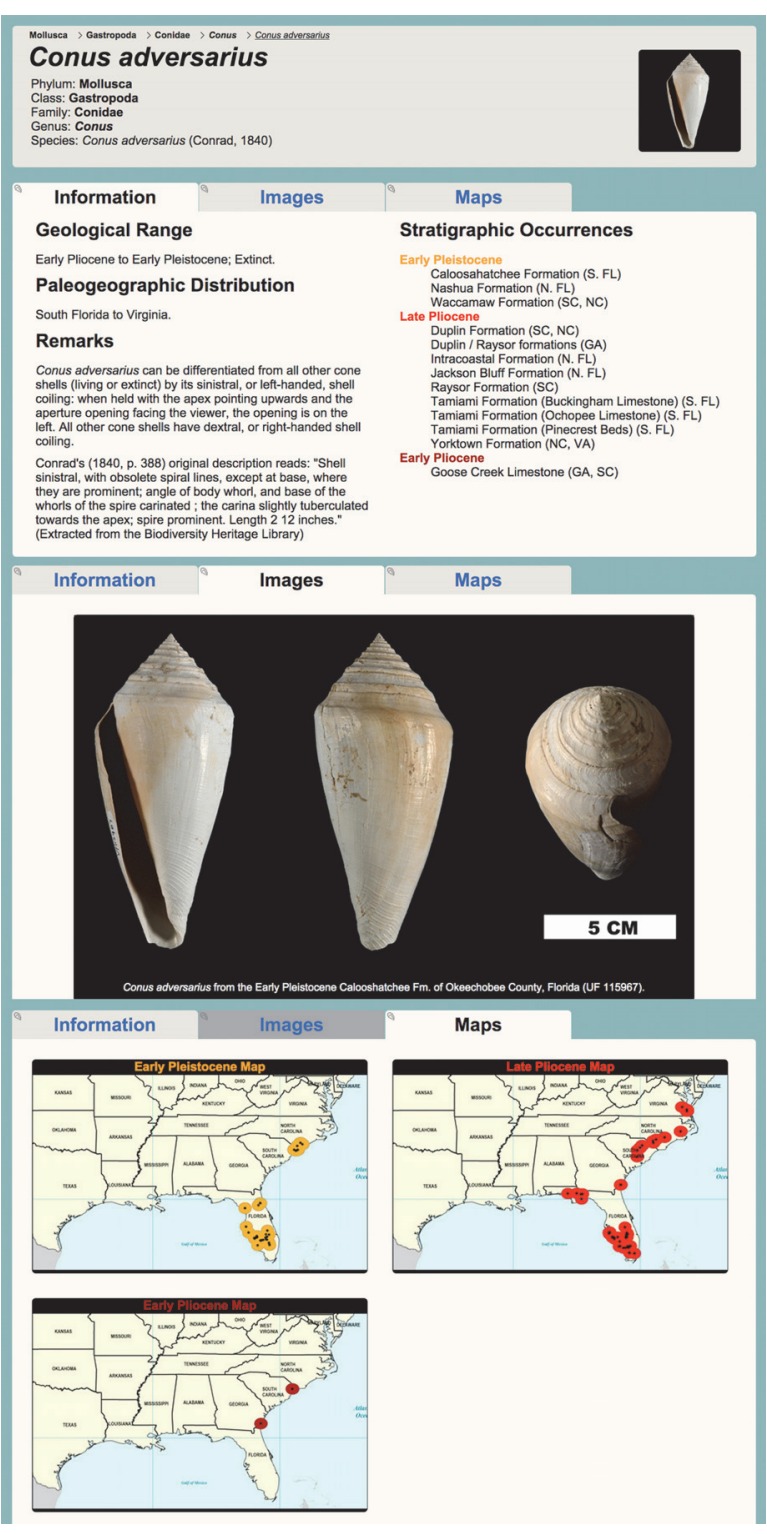

FIGURE 2. Composite screenshot of the Neogene Atlas page for the gastropod species Conus adversarius (neogeneatlas.org/species/conus-adversarius), showing the content provided under each of the three tabs (additional images of this species are viewable online).

Florida to Virginia) and using static maps that characterize species occurrences within discrete time intervals (e.g., late Pliocene, middle Pleistocene). The Ordovician Atlas includes dynamic, interactive maps derived from georeferenced data shared with iDigBio (see Figure 1). For an example, see the occurrence map for the trilobite genus Flexicalymene at: www.ordovicianatlas.org/atlas/arthropoda/trilobita/phacopida/calymenidae/

flexicalymene/. Note that this map contains occurrence points for Flexicalymene beyond the Cincin- 


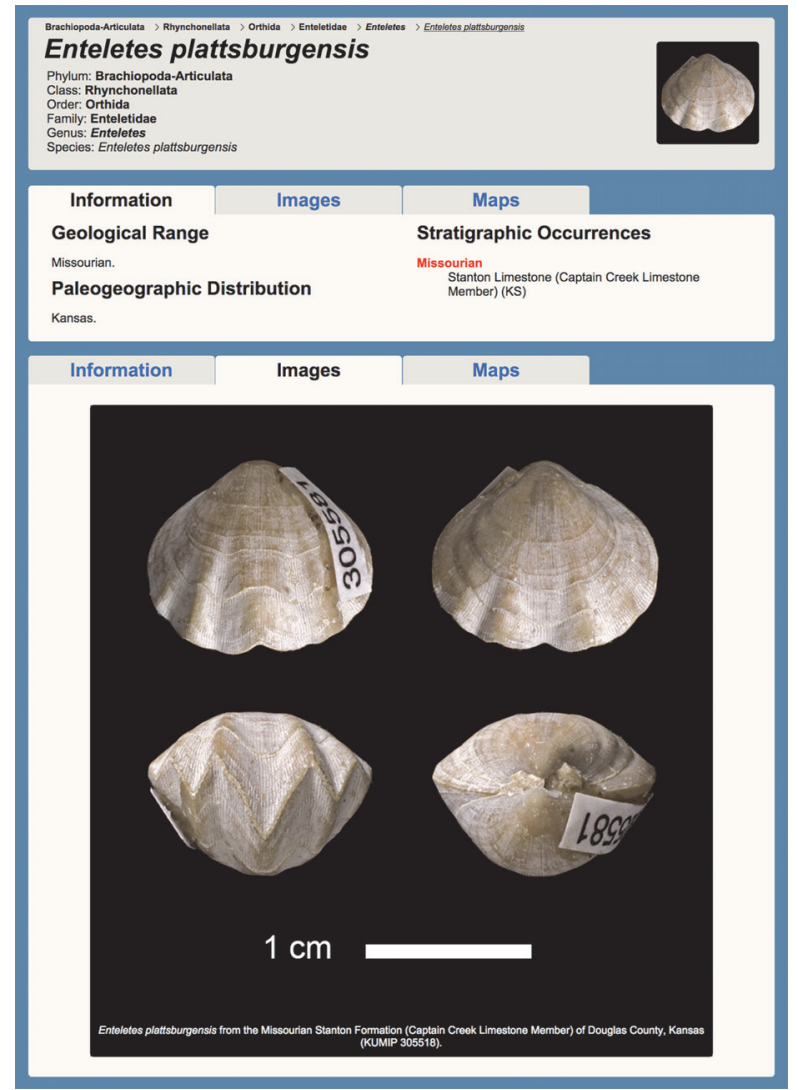

FIGURE 3. Composite screenshot of the Pennsylvanian Atlas page for the brachiopod species Enteletes plattsburgensis (pennsylvanianatlas.org/species/enteletes-plattsburgensis), showing the content provided under two of the three tabs.

nati region because it is constructed from all of the museum records of Flexicalymene that are currently within the iDigBio database, not only those from the museums directly associated with the Ordovician Atlas. Our goal is to eventually employ such maps on all three digital atlas websites. Species-level stratigraphic occurrence data on the Ordovician Atlas are presented at the sequence and formation levels as both shaded stratigraphic charts and listings; these data are presented as listings at the formation (and sometimes member) level on the Neogene and Pennsylvanian Atlases (see, respectively, Figures 2 and 3 ).

The spatiotemporal data underlying the geographic and stratigraphic occurrence records on each digital atlas are as robust as the underlying, digitized collections themselves, which have been taxonomically identified by the specialists who have worked with them over the years. Given that they are derived from the most important museum collections of fossils from the three regions of

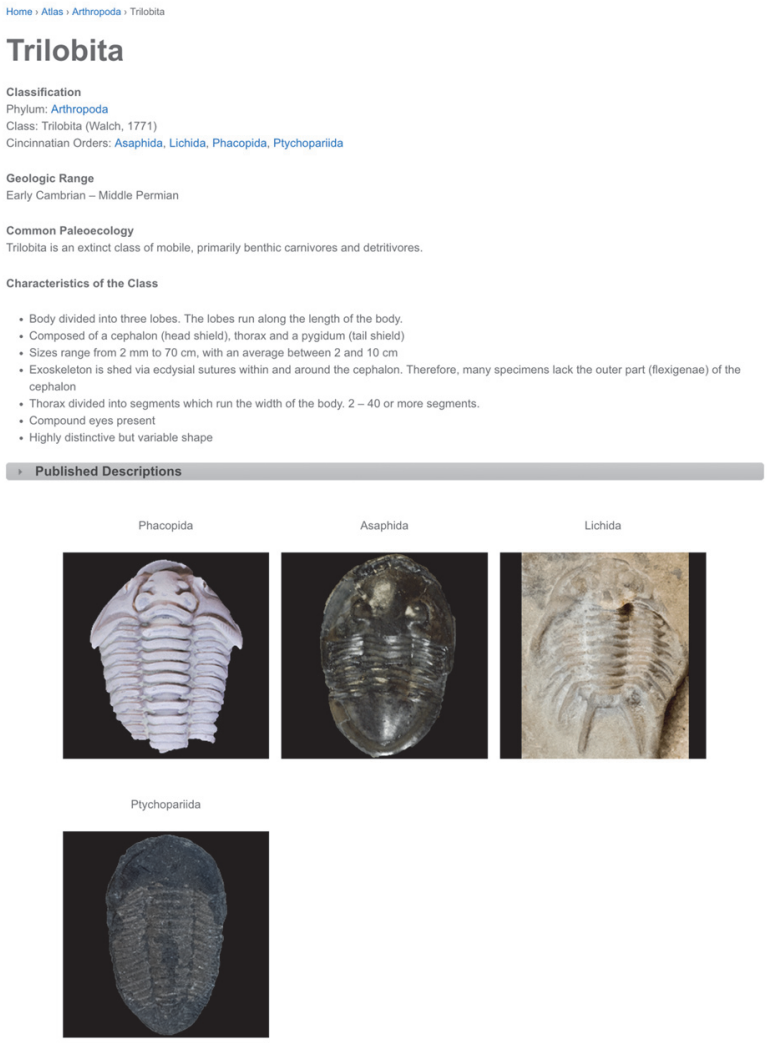

FIGURE 4. Higher level taxonomic information about trilobites from the Ordovician Atlas (www.ordovicianatlas.org/atlas/arthropoda/trilobita/), including links to the four orders of trilobites present in the Ordovician of the Cincinnati region. The bar labeled "Published Descriptions" drops down to provide additional information.

focus, we expect that these records are in many instances more complete than those that currently appear in the printed literature and databases developed primarily from the literature. One reason for this is because the printed literature is static, while many major museum collections are undergoing continuous curation (often following visits by taxonomic experts) and development as new collections are added to them. Another reason is that many published accounts of species occurrences may never have sought to be comprehensive (e.g, faunal lists for individual localities), thus giving a restricted view of the spatio-temporal distributions of individual taxa. All of the occurrence data associated with the digital atlas project are being made publically available via the respective institutional online databases (e.g., biodiversity.ku.edu/invertebrate-paleontology/collections/collections-search) and also through iDigBio (www.idigbio.org) (the only exceptions will be latitude and longitude data for fossils from a very limited number of sensitive 
localities). These occurrence data have the potential to address many interesting paleobiogeographic questions in novel ways, especially when analyzed in concert with predictive approaches such as ecological niche modeling (e.g., Peterson et al., 2011; Polly and Eronen, 2011), which has been successfully applied to both modern (e.g., Bentlage et al., 2013; Robison et al., 2011; Saupe et al., 2014b) and paleontological (e.g., Stigall Rode and Lieberman, 2005; Maguire and Stigall, 2009; Stigall, 2012, 2014; Saupe et al., 2014a; Myers et al., 2015; Saupe et al., 2015) datasets.

Finally, as mentioned, all three digital atlases feature high-quality images of fossils, and specimens are typically shown in multiple orientations to assist with identification (e.g., Figures 1-3). Each image includes a scale bar and caption with the specimen's museum catalog number. A Creative Commons Attribution-NonCommercial-ShareAlike 4.0 International license (creativecommons.org/ licenses/by-nc-sa/4.0/deed.en_US) is applied to each image so that they can be used in most nonprofit applications without restriction.

Species pages associated with the Ordovician Atlas currently have several additional features that will eventually be added to the Pennsylvanian and Neogene Atlases, including information about the paleoecology of individual species and lists and/or labeled figures indicating morphological features that are important for identifying specimens in hand sample (e.g., Figure 1).

\section{EDUCATIONAL POTENTIAL}

Besides providing new tools for identifying and better understanding fossils from particular regions, the digital atlases can be valuable educational resources for the general public and students of all ages. Each includes information on the geologic setting and stratigraphic framework for the focal region (e.g., the Neogene Atlas of Ancient Life, neogeneatlas.org/geology/). Additional information about fossil collecting locations, relevant links, and references used are currently available on the Ordovician Atlas and are under development for the other digital atlases.

Formal lesson plans are being developed in association with each digital atlas and for the project as a whole. K-12 exercises and lesson plans take advantage of the innate interest that many children have for fossils and are aligned with Next Generation Science Standards (www.nextgenscience.org/). Lesson plans currently deployed on the Ordovician Atlas site (www.ordovicianatlas.org/ resources-for-teachers/) were developed in collab- oration with science education faculty and utilize a 5E learning cycle approach for active learning (Bybee et al., 2006). This approach emphasizes early exploration of materials prior to explanation and elaboration of concepts. Some of these exercises (e.g., Stigall et al., in press) emphasize place-based education and facilitate investigations that prompt students to discover and describe how the environments where they live-as well as associated life forms-have changed over time. Other exercises under development for the $\mathrm{NeO}-$ gene Atlas will ask students to use map data to explore how ancient species responded to environmental changes, including whether the geographic ranges of individual species changed over time (e.g., by comparing the late Pliocene and early Pleistocene occurrence maps shown in Figure 2). Students will also be asked to quantify changes in biodiversity patterns over time and recognize events such as faunal turnovers.

The digital atlases on their own are useful resources for students in university paleontology classes tasked with identifying a set of specimens collected in the field. In addition, exercises appropriate for college-level historical geology or paleontology laboratories have also been developed (e.g., Casey and Lieberman, 2014) and more are in development. For instance, one of these will begin with a digital scavenger hunt, which will require students to explore the digital atlases in search of taxa that show particular morphological features. The goal of such an exercise is to familiarize students with the diversity and variation of morphological forms within and across taxonomic groups, leading them to realize that this variation is useful for understanding phylogenetic relationships. First, students will be presented with illustrations and descriptions of morphological features, for example, different types of bivalve hinge dentition. Then, students will be directed to search the digital atlases for examples of species (or higher taxa) that show a particular feature, for example, a bivalve with a heterodont hinge. An exercise like this could be done by students at home prior to attending a corresponding laboratory featuring actual fossils, or could be done in lieu of a physical laboratory exercise. The latter will be advantageous for courses taught entirely online, or at institutions that do not have extensive on-site teaching collections. Once students are familiar with the diversity of morphological forms (i.e., characters and character states) within taxonomic groups-as well as the corresponding terminology-they will be presented with a list of taxa to research. Based 
on the distribution of character states shared among those taxa, they will be asked to construct a simple phylogenetic hypothesis in which character states are mapped at the appropriate nodes on the tree.

These are just a few of the many ways in which the digital atlases can be used as K-16 educational resources. We expect and hope that educators will find additional ways to use the products of the Digital Atlas of Ancient Life project in their classrooms.

\section{CONCLUSION}

The science of paleontology - to its great benefit-has long embraced data digitization as a means to better understand the history of life on Earth. The utility of the resulting datasets, and the variety of the questions we can address using them, depends ultimately on the quality of our fundamental data: correctly identified specimens in museum drawers that are from well-constrained stratigraphic and geographic settings. The field of paleontology has lagged in the development of digital resources to help assist workers with the identification of fossil material. We propose the Digital Atlas of Ancient Life project as one potential model for how such identification guides might be organized and the types of information that they may contain. In addition to their utility for identifying fossils from the regions of current focus, we hope that the digital atlases will draw greater attention to the general problem they aim to alleviate.

\section{ACKNOWLEDGMENTS}

We thank the following individuals for their contributions to the Digital Atlas of Ancient Life project: N. Abdollahian, M. McEvers, A. Lenci, E. Lenci, and N. Sylva (current and former students at San José State University); B.A. Kittle, R. Portell, and S. Roberts, (Florida Museum of Natural History); R. Ahuja, J.E. Bauer, H.-M. R. Brame, T. Henderson, D. Hermanns, A.L. Lam, W. Parker, Z. Zeszut (current and former students at Ohio University); B.R. Hunda (Cincinnati Museum Center); K. Hauer (Miami University Limper Museum); and U. Farrell and M. Casey (University of Kansas). Additionally, we thank an anonymous reviewer for their comments on an earlier draft of this manuscript. The Digital Atlas of Ancient Life project is supported by Ohio University and also National Science Foundation grants EF-1206769 to JRH, EF-1206750 to ALS, and EF-1206757 to BSL.

\section{REFERENCES}

Algeo, T.J. and Heckel, P.H. 2008. The Late Pennsylvanian Midcontinent Sea of North America: a review. Palaeogeography, Palaeoclimatology, Palaeoecology, 268:205-221.

Allmon, W.D. In press. Studying species in the fossil record: a review and recommendations for a more unified approach. In Allmon, W.D. and Yacobucci, M.M. (eds.), Species and Speciation in Fossil Animals. University of Chicago Press, Chicago, IL.

Allmon, W.D., Rosenberg, G., Portell, R.W., and Schindler, K.S. 1996. Diversity of Pliocene-Recent mollusks in the western Atlantic: extinction, origination, and environmental change, p. 271-302. In Jackson, J.B.C., Budd, A.F., and Coates, A.G. (eds.), Evolution and Environment in Tropical America, University of Chicago Press, Chicago, IL.

Bentlage, B., Peterson, A.T., Barve, N., and Cartwright, P. 2013. Plumbing the depths: extending ecological niche modelling and species distribution modelling in three dimensions. Global Ecology and Biogeography, 22:952-961.

Bybee, R.W., Taylor, J.A., Gardner, A., Van Scotter, P., Powell, J.C., Westbrook, A., and Landes, N. 2006. The BSCS 5E Instructional Model: Origins and Effectiveness. BSCS, Colorado Springs, CO.

Campbell, L.D. 1993. Pliocene Molluscs from the Yorktown and Chowan River Formations in Virginia. Virginia Division of Mineral Resources Publication, 127:1-259.

Casey, M.M. and Lieberman, B.S. 2014. Beyond memorization: an intermediate-level paleontology activity that integrates anatomy, ecology, and macroevolutionary theory using trilobites. Evolution: Education and Outreach, 7:20.

Chapman, A.D. and Wieczorek, J. (eds.) 2006. Guide to Best Practices for Georeferencing. Global Biodiversity Information Facility, Copenhagen, 80 pp.

Davis, R.A. (ed.) 1998. Cincinnati Fossils: An Elementary Guide to the Ordovician Rocks and Fossils of the Cincinnati, Ohio, Region. Cincinnati Museum Center, Cincinnati, $\mathrm{OH}$.

DuBar, J.R.1958. Stratigraphy and paleontology of the late Neogene strata of the Caloosahatchee River area of southern Florida. Florida Geological Survey Bulletin, 40:1-267.

Feldmann, R.M. and Hackathorn, M. (eds.) 1996. Fossils of Ohio. Ohio Division of Geological Survey Bulletin, 70:1-577.

Hendricks, J.R. 2009. The genus Conus (Mollusca: Neogastropoda) in the Plio-Pleistocene of the southeastern United States. Bulletins of American Paleontology, 375:1-180.

Hendricks, J.R. 2015. Glowing seashells: diversity of fossilized coloration patterns on coral reef-associated cone snail (Gastropoda: Conidae) shells from the Neogene of the Dominican Republic. PLOS ONE, journals.plos.org/plosone/article?id=10.1371/journal.pone.0120924. 
Hendricks, J.R., Saupe, E.E., Myers, C.E., Hermsen, E.J., and Allmon, W.D. 2014. The generification of the fossil record. Paleobiology, 40:511-528.

Holland, S.M. and Patzkowsky, M.E. 2007. Gradient ecology of a biotic invasion: biofacies of the type Cincinnatian Series (Upper Ordovician), Cincinnati, Ohio region, USA. Palaios, 22:392-407.

Holterhoff, P.F. 1996. Crinoid biofacies in Upper Carboniferous cyclothems, midcontinent North America: faunal tracking and the role of regional processes in biofacies recurrence. Palaeogeography, Palaeoclimatology, Palaeoecology, 127:47-81.

Kallmeyer, J.W. and Donovan, S.K. 1998. Tenuicrinus longibasalis, a new disparid in the subfamily Cincinnaticrininae, Upper Ordovician, Edenian, north central Kentucky. Northeastern Geology and Environmental Sciences, 20:28-38.

Linsley, D.M. 1994. Devonian Paleontology of New York. Paleontological Research Institution, Special Publication 21.

Lyons, W.G. 1991. Post-Miocene species of Latirus Montfort, 1810 (Mollusca: Fasciolariidae) of southern Florida, with a review of regional marine biostratigraphy. Bulletin of the Florida Museum of Natural History, Biological Sciences, 35:131-208.

MacLeod, N. 2001. PaleoBase: Macrofossils Part 1. Wiley-Blackwell, Hoboken, NJ.

MacLeod, N. 2003. PaleoBase: Macrofossils Part 2. Wiley-Blackwell, Hoboken, NJ.

MacLeod, N. 2010. PaleoBase: Macrofossils Part 3. Wiley-Blackwell, Hoboken, NJ.

MacLeod, N. and Henderson, A. 2007. PaleoBase: Microfossils, $2^{\text {nd }}$ edition. Wiley-Blackwell, Hoboken, NJ.

Maguire, K.C. and Stigall, A.L. 2009. Using ecological niche modeling for quantitative biogeographic analysis: a case study of Miocene and Pliocene Equinae in the Great Plains. Paleobiology, 35:587-611.

Meyer, D.L. and Davis, R.A. 2009. A Sea without Fish: Life in the Ordovician Sea of the Cincinnati Region. Indiana University Press, Bloomington, IN.

Morris, R.W. and Felton, S.H. 1993. Symbiotic association of crinoids, platyceratid gastropods, and Cornulites in the Upper Ordovician (Cincinnatian) of the Cincinnati, Ohio region. Palaios, 8:465-476.

Myers, C.E., Stigall, A.L., and Lieberman, B.S. 2015. PaleoENM: applying ecological niche modeling to the fossil record. Paleobiology, 41:226-244.

Olsson, A.A. and Harbison, A. 1953. Pliocene Mollusca of southern Florida with special reference to those from North Saint Petersburg. Special chapters on Turridae by W. G. Fargo and Vitrinellidae by H.A. Pilsbry. The Academy of Natural Sciences of Philadelphia Monograph 8, 1-457.

Olsson, A.A. and Petit, R.E. 1964. Some Neogene Mollusca from Florida and the Carolinas. Bulletins of American Paleontology, 47:509-574.
Oxford English Dictionary Online. 2014. Oxford University Press. www.oed.com/view/Entry/ 12536? rskey=AykBKv\&result=1\&isAdvanced=false (accessed November 05, 2014).

Peterson, A.T., Soberón, J., Pearson, R.G., Anderson, R.P., Martínez-Meyer, E., Nakamura, M., and Araújo, M.B. 2011. Ecological Niches and Geographic Distributions, Princeton University Press, Princeton, NJ.

Peterson, C. and Peterson, B. 2008. Southern Florida's Fossil Seashells. Self published. Blue Note Books, Cocoa Beach, FL.

Peterson, R.T. 1980. Peterson's Field Guides: Eastern Birds. Houghton Mifflin, Boston, MA.

Petuch, E.J. 1991. New Gastropods from the Plio-Pleistocene of Southwestern Florida and the Everglades Basin. Special Publication 1. W.H. Dall Paleontological Research Center, Florida Atlantic University, Boca Raton, FL.

Petuch, E.J. 1994. Atlas of Florida Fossil Shells (Pliocene and Pleistocene Marine Gastropods). The Graves Museum of Archaeology and Natural History, Dania, Florida and Chicago Spectrum Press.

Polly, P.D. and Eronen, J.T. 2011. Mammal associations in the Pleistocene of Britain: implications of ecological niche modelling and a method for reconstructing palaeoclimate, p. 279-304. In Ashton, N., Lewis, S., and Stringer, C. (eds.), The Ancient Human Occupation of Britain. Elsevier.

Robison, L.M., Elith, J., Hobday, A.J., Pearson, R.G., Kendall, B.E., Possingham, H.P., and Richardson, A.J. 2011. Pushing the limits in marine species distribution modelling: lessons from the land present challenges and opportunities. Global Ecology and Biogeography, 20:789-802.

Rode, A.L. and Lieberman, B.S. 2002. Phylogenetic and biogeographic analysis of Devonian phyllocarid crustaceans. Journal of Paleontology, 76:269-284.

Saupe, E.E., Hendricks, J.R., Portell, R.W., Dowsett, H.J., Haywood, A., Hunter, S.J., and Lieberman, B.S. 2014a. Macroevolutionary consequences of climate change on niche evolution in marine molluscs over the past 3 million years. Proceedings of the Royal Society, Series B, 281:20141995. doi:10.1098/ rspb.2014.1995

Saupe, E.E., Hendricks, J.R., Peterson, A.T., and Lieberman, B.S. 2014b. Climate change and marine molluscs of the western North Atlantic: future prospects and perils. Journal of Biogeography, 41:1352-1366. doi:10.1111/jbi.12289

Saupe, E.E., Qiao, H., Hendricks, J.R., Portell, R.W., Hunter, S.J., Soberón, J., and Lieberman, B.S. In press. Niche breadth and geographic range size as determinants of species survival on geological time scales. Global Ecology and Biogeography. doi:10.1111/geb.12333

Selden, P.A. 2012. Treatise on Invertebrate Paleontology: a work in progress. Palaios, 27:439-442. 
Sepkoski, J.J. Jr. 2002. A compendium of fossil marine animal genera. Jablonski, D. and M. Foote (eds.), Bulletins of American Paleontology, 363:1-560.

Stanley, S.M. 1986. Anatomy of a regional mass extinction: Plio-Pleistocene decimation of the western Atlantic bivalve fauna. Palaios, 1:17-36.

Stigall, A.L. 2010. Using GIS to assess the biogeographic impact of species invasions on native brachiopods during the Richmondian invasion in the Type-Cincinnatian (Late Ordovician, Cincinnati Region). Palaeontologia Electronica, 13.1.5A.

Stigall, A.L. 2012. Using ecological niche modeling to evaluate niche stability in deep time. Journal of Biogeography, 39:772-781.

Stigall, A.L. 2014. When and how do species achieve niche stability over long time scales? Ecography, 37:1123-1132.

Stigall A.L., Hembree, D.I., Gierlowski-Kordesch, E.H., and Weismiller, H.C. 2014a. Evidence for a dioecious mating system in Early Jurassic Hardapestheria maxwelli gen. et sp. nov. (Crustacea, Branchiopoda, Spinicaudata) from the Kalkrand Formation of Namibia. Palaeontology, 57:127-140.
Stigall, A.L., Bauer, J.E., and Brame, H.M.R. 2014b. The Digital Atlas of Ordovician Life: digitizing and mobilizing data for paleontologists and the public. Estonian Journal of Earth Sciences, 63:312-316.

Stigall, A.L., Dani, D.E., Sickel, A.J., and Helfrich, S.A. In press. Oceans of Ohio: Using observations of fossils to reconstruct ancient environments. Science Scope.

Stigall Rode, A.L., and Lieberman, B.S. 2005. Using environmental niche modeling to study the Late Devonian biodiversity crisis, p. 93-127. In Over, D.J., Morrow, J.R., and Wignall, P.B. (eds.), Understanding Late Devonian and Permian-Triassic Biotic and Climatic Events: Towards and Integrated Approach, Elsevier BV, The Netherlands.

Wilson, K.A. 2014. Field Guide to the Devonian Fossils of New York. Paleontological Research Institution, Special Publication, 44.

Wright, D.F. and Stigall, A.L. 2013. Phylogenetic revision of the Late Ordovician orthid brachiopod genera Plaesiomys and Hebertella from North America. Journal of Paleontology, 87:1107-1128.

Wright, D.F. and Stigall, A.L. 2014. Species-level phylogenetic revision of the Ordovician orthide brachiopod Glyptorthis from North America. Journal of Systematic Palaeontology, 12:893-906. 